\title{
Presence of Phytophthora cinnamomi Rands. in avocado orchards in Azapa and Codpa valleys, Chile
}

\author{
Presencia de Phytophthora cinnamomi Rands. en huertos de palto \\ en los valles de Azapa y Codpa, Chile
}

\author{
Germán Sepúlveda-Chavera ${ }^{1 *}$, Ricardo Salvatierra-Martínez ${ }^{1}$, Cristián Bilbao-Apata, \\ Paulina Sepúlveda-Ramírez ${ }^{2}$, Marjorie Allende-Castro ${ }^{3}$, Jorge Alache-González
}

\begin{abstract}
Soil avocado with symptoms of chlorosis and defoliation that were associated with Phytophthora cinnamomi in the orchards of two valleys (Azapa and Codpa) in northern Chile were explored, in this soil the $\mathrm{EC}$ and $\mathrm{pH}$ was measured in the saturation extract. The phytopathogen was successfully isolated using as bait circles of leaves of Eucalyptus globulus, was identified in only one of the eighteen sectors prospected in Azapa Valley (5.6\%), while in the valley of Codpa P. cinnamomi was identified in all orchards prospected (100\%). Suggesting that in Codpa symptoms in plants are produced by P. cinnamomi, and in the valley of Azapa is rather due to salt toxicity and other soil physicochemical characteristics. The plant pathogen was isolated and inoculated Hass avocado plants, after 30 days affected plants developed symptoms as chlorosis, defoliation, death of branches and tree. The fungus was isolated from inoculated plants and pathogenicity was confirmed. The $\mathrm{CO}_{2}$ assimilation was measured with a LI-COR 6200 in five healthy and five diseased plants obtaining significant differences $(p<0.05)$ showing that the disease affects photosynthesis.

Key words: Root rot, MS media.
\end{abstract}

\section{RESUMEN}

Fueron prospectados huertos de paltos con árboles que presentaban síntomas asociados a Phytophthora cinnamomi en dos valles en el norte de Chile (Azapa y Codpa), se tomó suelo de estos árboles para la identificación del fitopatógeno y paralelamente se midió CE y el pH en el extracto de saturación. El fitopatógeno se aisló con éxito utilizando como cebo círculos de hoja de Eucalipto globulus. P. cinnamomi fue identificado en solo uno de los dieciocho sectores prospectados en el valle de Azapa (5,6\%), mientras que en el valle de Codpa P. cinnamomi fue identificado en todos los huertos prospectados (100\%). Lo que sugiere que en Codpa los síntomas en las plantas son producidos por $\mathrm{P}$. cinnamomi, mientras que en el valle de Azapa es más bien debido a toxicidad por exceso de sales y posiblemente otras características fisicoquímicas de los suelos. El fitopatógeno fue aislado y se inocularon plantas de palto Hass, después de 30 días las plantas afectadas desarrollaron síntomas como clorosis, defoliación, muerte de ramas y árboles. El hongo fue aislado de plantas inoculadas y la patogenicidad fue confirmada. Fue medida la asimilación de $\mathrm{CO}_{2}$ con una LICOR 6000 en cinco plantas enfermas y cinco sanas obteniendo significativas diferencias $(p<0,05)$ demostrando que la enfermedad afecta la fotosíntesis.

Palabras clave: Pudrición de la raíz, medio MS, palto, Phytophthora.

\section{Introduction}

Chile has a variety of climates, including Semiarid Subtropical Mediterranean and Mediterranean, both of which are favorable for avocado cultivation (Papadakis, 1966). The Region of Arica and Parinacota has a desert climate, with microclimates in several areas with high potential for avocado production.
There are a number of factors that limit avocado production, especially various diseases. The avocado root rot caused by Phytophthora cinnamomi Rands is one of the most important and devastating diseases of avocados in Chile and in the world (Zentmyer, 1980 Zentmyer, et al., 1994; Erwin y Ribeiro, 1996). It is normally associated with poorly drained soils, especially clay soils, since water is the fundamental factor for the dissemination of spores (Besoain

1 Departamento de Recursos Ambientales, Facultad de Ciencias Agronómicas, Universidad de Tarapacá, Avda. General Velázquez 1775, Arica, Chile.

2 Instituto de Investigaciones Agropecuarias (INIA) La Platina, Avda. Santa Rosa 11610, La Pintana, Santiago, Chile.

3 Instituto de Investigaciones Agropecuarias (INIA - URURI), Magallanes 1865, Arica, Región de Arica y Parinacota. Chile.

* Corresponding author: e-mail: gsepulve@uta.cl

Fecha de Recepción: 29 Octubre, 2012.

Fecha de Aceptación: 04 Enero, 2013. 
et al., 2005; Ferrari and Ramirez, 1998). In central Chile it is a frequent disease in avocado orchards (Besoain et al., 2005; Latorre, 1992; Latorre et al., 1998; Vergara, 1957). However, its presence and distribution in other zones of the country has not been studied.

The objective of this study were to prospect P. cinnamomi in soils planted with avocado trees in the Azapa and Codpa valleys of the Arica and Parinacota Region, Chile, and to evaluate the effect of artificial inoculation of isolates of P. cinnamomi on net assimilation rate of $\mathrm{CO}_{2}$ in avocado trees. The study provides information about the phytopathogenic potential and presence of this disease in Northern Chile, adding to our knowledge of the distribution of this plant pathogen in the country.

\section{Materials and Methods}

\section{Survey}

28 avocado orchards were surveyed between April and July 2009, 18 in the Azapa valley and 10 in Codpa valley in each orchard three trees with symptoms were selected. The Azapa Valley has two parallel roads one is the A-27 for sampling it was separate in sectors respect Arica city, the high sector ( $\mathrm{km} 20$ to 45), medium (12 to 20) and low (1 to 12 $\mathrm{km}$ ) and the other is "Las Maitas" road that it was separated into Sectors. On Another hand Codpa is a small town that was delimited for sampling only in terms of the orchards. Soil and roots were collected in the first $30 \mathrm{~cm}$ of the soil profile, in 4 different cardinal points in the irrigation zone. Samples were collected in polyethylene bags, labeled and taken to laboratory. Before isolating the fungus, the soil was dried at room temperature and sieved. Two collections of samples were made at the same locations on different dates.

\section{Isolation (bait preparation)}

The isolation of $P$. cinnamomi was made by a modification of the method described by Dhingra and Sinclair (1985). A suspension of soil (20 $\mathrm{g}$ sieved soil diluted in $15 \mathrm{~mL}$ sterile distilled water) was prepared in sterile Petri plates, after which 20 disks of $5 \mathrm{~mm}$ diameter of Eucalyptus globulus Labill. leaves were placed on the soil suspension. Three replicates were used for each sample. Petri plates were incubated under artificial light at $25^{\circ}$ to $30^{\circ} \mathrm{C}$ for 10 days, making regular observations with an optical microscope. Sporangia were observed on the edge and surface of the eucalyptus leaf baits, and transfered to a selective agar media (MS) (piramicin, ampicillin, Rifanpicin, PCNB and Himexazol; PARPH) (Alvarado-Rosales et al., 2008) and water agar (WA) and incubated at $25^{\circ} \mathrm{C}$ for identification and inoculum preparation for pathogenicity test.

\section{Identification}

The identification was based on the colony morphology of the mycelia and sporangia in agreement to the methodology proposed by Erwin and Ribeiro (1996). Fungal structures were observed after 3 to 4 days, and characteristics of the mycelia, hyphae and presence of hyphal swellings were recorded. Different morphological characteristics of sporangia and chlamydospores of the isolates were also evaluated, using a microscope (Motic $310^{\mathrm{TM}}$, Mod. BA 310, USA) at 400 and $1,000 \mathrm{X}$ (Arenas, 1998).

\section{Pathogenicity tests}

Twenty potted of Hass avocado trees of 3 year old of similar size were used. Three strains of P. cinnamomi, PCD1, PCD2 y PAZ1 (two from Codpa Valley and one from Azapa Valley), were inoculated to conduct pathogenicity tests. Plants were inoculated with 5 disks of MS medium ( 0.8 $\mathrm{cm}$ diameter) with mycelium of 5 to 9 days, in two diagonal cuts in the bark, $10 \mathrm{~cm}$ from the ground. After inoculation the cuts were sealed with Parafilm tape and black polyethylene. Five replicates were used per strain.

\section{Net assimilation rate of $\mathrm{CO}_{2}$ in avocado trees infected with $P$. cinnamomi, and leaf temperature, electrical conductivity (EC) and soil acidity}

The net assimilation rate of $\mathrm{CO}_{2}$ and leaf temperature, of the inoculated avocado plants, was measured in 3 young leaves of each tree with a closed photosynthesis system (IRGA model LI-COR 6200). The electrical conductivity (EC) was determined in saturation extract with Electrolytical Conductivity meter WTW LF 330 at $25^{\circ} \mathrm{C}$, and soil acidity was determined by $\mathrm{pH}$ meter board (EXTECH 211 990). 


\section{Experimental Design}

To determine the effect of the disease on the $\mathrm{CO}_{2}$ rate completely randomized design was used with five replicates ( 5 trees) under greenhouse conditions, applied the Kruskal-Wallis test for $\mathrm{CO}_{2}$ assimilation results and Tukey test for media separation. All for a significance level of $\alpha \leq 0.05$. Analyses were performed using the statistical software Statgraphics Plus 5.1.

\section{Results and Discussion}

\section{Presence of $P$. cinnamomi soils planted with avocado}

P. cinnamomi sectors in was found in only one of the eighteen prospected sectors $\left(18^{\circ} 31.901\right.$ 'S; $70^{\circ} 09.990^{\prime} \mathrm{W}$ and $973 \mathrm{~m}$. a. s. 1$) .5 .6 \%$ positive sector (4 of 108 samples; $3.7 \%$ ), in the two sampling dates (Table 1). In the Codpa valley P. cinnamomi was found in all prospected sectors. $100 \%$ sector positive ( 54 positive of 60 samples; $90 \%$ ), in the two sampling dates (Table 2). Due for the colonization of bait that was determined by tissue color changes from green to brown, and presence of sporangia on the edge of the discs. In Codpa valley the symptoms of the disease were corroborated with the results obtained with the baits (Table 1 y 2). In Azapa valley the symptoms had no correlation with the pathogen. Morphologically the sporangia found were non papillated, ovoid, ellipsoidal to elongate ellipsoidal, with a compact apex, not outstanding, tapering or rounded at the base (Erwin and Ribeiro, 1996) (Figure 1F). The isolates showed cenocytic and hyaline mycelia, well branched at right angles (Figure 1D and 1E), with abundant presence of chlamydospores. Absence of septa in the mycelium, presence of hyphal expansion coupled with a botriosum aspect, non-papillate ovoid sporangia, pyriform or ellipsoidal to elongate-ellipsoid with compact apex not prominent, tapering towards the base, are characters typical of the species (Erwin and Ribeiro, 1996). The dimensions of the sporangia were 44-73 (56.4) x 28-43 (33.7) $\mu \mathrm{m}$, consistent with the range defined by Besoain et al. (2005) and Zentmyer et al.(1994) defined values of 43-75 x 24-47 $\mu \mathrm{m}$ for these structures. MS selective medium

Table 1. Presence of P. cinnamomi, CE y pH in soil prospected in the Azapa valley.

\begin{tabular}{|c|c|c|c|c|c|c|}
\hline \multirow[t]{2}{*}{ Place } & \multirow[t]{2}{*}{ Sample } & \multirow[t]{2}{*}{$\mathrm{Km} /$ sector } & \multicolumn{2}{|c|}{$\begin{array}{c}\text { Presence of } \\
\text { Phytophthora cinnamomi }\end{array}$} & \multirow{2}{*}{$\begin{array}{c}\mathrm{pH} \\
\text { Average* }\end{array}$} & \multirow{2}{*}{$\begin{array}{c}\mathrm{EC}\left(\mathrm{dS} \mathrm{cm}^{-1}\right) \\
\text { Average }\end{array}$} \\
\hline & & & First Survey & Second Survey & & \\
\hline \multirow{4}{*}{ Sector alto } & 1 & 42 & - & - & 6.5 & 1.35 \\
\hline & 2 & 40 & - & - & 4.7 & 8.25 \\
\hline & 3 & 35 & - & - & 6.1 & 2.7 \\
\hline & 4 & 34 & - & - & 6.7 & 1.55 \\
\hline \multirow{4}{*}{ Sector medio } & 1 & 30 & - & - & 6.9 & 1.5 \\
\hline & 2 & 21 & - & - & 6.9 & 0.95 \\
\hline & 3 & 16 & + & + & 6.9 & 0.65 \\
\hline & 4 & 15 & - & - & 6.6 & 1.45 \\
\hline \multirow{3}{*}{ Sector bajo } & 1 & 12 & - & - & 6.7 & 2.15 \\
\hline & 2 & $2 \frac{1 / 2}{2}$ & - & - & 7.0 & 1.15 \\
\hline & 3 & 11 & - & - & 7.1 & 2.2 \\
\hline \multirow{7}{*}{ Sector cerro sombrero } & 1 & Llolas & - & - & 7.0 & 1.85 \\
\hline & 2 & Alto Ramírez & - & - & 6.3 & 1.32 \\
\hline & 3 & Alto Ramírez & - & - & 7.0 & 2.1 \\
\hline & 4 & Alto Ramírez & - & - & 6.7 & 2.1 \\
\hline & 5 & Alto Ramírez & - & - & 7.0 & 2.3 \\
\hline & 6 & Alto Ramírez & - & - & 6.9 & 2.4 \\
\hline & 7 & Alto Ramírez & - & - & 6.9 & 1.6 \\
\hline
\end{tabular}

* $\quad$ EC and $\mathrm{pH}$ each value is the average of 4 repetitions.

* Sign (-) negative sample for P. cinnamomi, (+) positive for P. cinnamomi. 
Table 2. Presence of P. cinnamomi, $\mathrm{CE} \mathrm{y} \mathrm{pH}$ in soil prospected in the Codpa valley.

\begin{tabular}{|c|c|c|c|c|}
\hline \multirow{2}{*}{ Sample } & \multicolumn{2}{|c|}{ Presence of Phytophthora cinnamomi } & \multirow{2}{*}{$\begin{array}{c}\mathrm{pH} \\
\text { Average }\end{array}$} & \multirow{2}{*}{$\begin{array}{c}\mathrm{EC}\left(\mathrm{dS} \mathrm{cm}^{-1}\right) \\
\text { Average }\end{array}$} \\
\hline & First Survey & Second Survey & & \\
\hline 1 & + & + & 7.5 & 0.73 \\
\hline 2 & + & + & 7.1 & 0.64 \\
\hline 3 & + & + & 7.2 & 1.35 \\
\hline 4 & + & + & 7.2 & 0.70 \\
\hline 5 & + & + & 7.0 & 1.08 \\
\hline 6 & + & + & 6.9 & 1.19 \\
\hline 7 & + & + & 6.4 & 0.87 \\
\hline 8 & + & + & 6.7 & 0.93 \\
\hline 9 & + & + & 6.9 & 1.08 \\
\hline 10 & + & + & 6.8 & 1.25 \\
\hline
\end{tabular}

* EC and $\mathrm{pH}$ each value is the average of 4 repetitions.

* $\quad$ Sign (-) negative sample for P. cinnamomi, (+) positive for P. cinnamomi.

was effective for the isolation of $P$. cinnamomi from $E$. globulus leaf baits; were obtain sporangia and mycelium of the fungus. MS media allowed isolation of reproductive elements sporangia, zoospores, oogonia and antheridia, but oospores were not observed. Additionally, colony growth showed the typical "camellia flower" appearance and changes of color in the MS medium. The fungus colonized the entire dish after 10 days of culture. Observations under an optical microscope showed the presence of non-papillate sporangia of variable size and shape (Figure 1B and 1C).

In the Codpa valley the $\mathrm{EC}$ of the soil ranged from 0.64 to 1.35 , with the average of $0,95 \mathrm{dS} \mathrm{m}^{-1}$ an acceptable range for the specie (Gardiazabal and Rosenberg, 1998). In Azapa Valley the EC ranged from 0.65 to 8.25 with average of $2.1 \mathrm{dS} \mathrm{m}^{-1}$ (Table 1 ), Salinity levels in soil of Azapa valley, that in one sector exceeded $8 \mathrm{dS} \mathrm{m}^{-1}$, may be the reason for the presence of chlorosis and defoliation that were associate with symptoms of $P$. cinamomi before the study. Gardiazabal and Rosenberg (1998), argued that if the EC reaches levels above $2 \mathrm{dS} \mathrm{m}^{-1}$ there may be a $10 \%$ of yield reduction, and chlorosis symptoms due the avocado is sensitive to salinity. In this sense it is important to note that there may be negative relationships between soil salinity and the presence of Phytophthora since as shown in Table 1 and 2, soils of Azapa had an EC average of $2.1 \mathrm{dS} \cdot \mathrm{m}^{-1}$ and the plant pathogen was detected only in one of the orchards studied, where salinity was less than the average $\left(0.65 \mathrm{dS} \cdot \mathrm{m}^{-1}\right)$, while in Codpa valley the average EC of the soil was
$0.98 \mathrm{dS} \bullet \mathrm{m}^{-1}$ and the plant pathogen was detected in all the tested orchards, however more research is needed to demonstrate that hypothesis.

The $\mathrm{pH}$ of the soil in the orchards of the Codpa Valley ranged from 6.3 to 7.5, while in the Azapa Valley $\mathrm{pH}$ fluctuated between 4.7 and 5.7, allowing the crop to develop without limitations. Values above 8 restrict the development of the tree, especially iron deficiencies induced by the presence of carbonates in the soil (Gardiazabal and Rosenberg, 1998). The avocado requires soil $\mathrm{pH}$ values between 5.5 and 6.5 and in semi-arid climates should not exceed 7.5 (Whiley et al., 2007). Accordingly, there is no problem for the normal development of the crop in these soils (Table 1 y 2). Zentmyer (1980) indicated that $P$. cinnamomi optimum growth is in acidic media. Chee and Newhook (1965), achieved a good production of sporangia in non-sterile soil extracts with $\mathrm{pH}$ between 4 and 7 . Subsequently, Zentmyer (1980) determined that the optimum $\mathrm{pH}$ for sporangia production fluctuates between 6 and 6.5 , therefore this fungus should growth without any problem in the soils studied. Likewise, $\mathrm{pH}$ should be between 5 and 7 for chlamydospore germination, although it also germinated at $\mathrm{pH}$ values of 3 and 9. These indicate that the soil had adequate conditions for the development of the pathogen.

In addition of all that, the symptoms may be related to toxicity of some salts present in the soil (Table 1), also the irrigation frequency and volume of water are very important for disease development, aspects not studied in this work. 

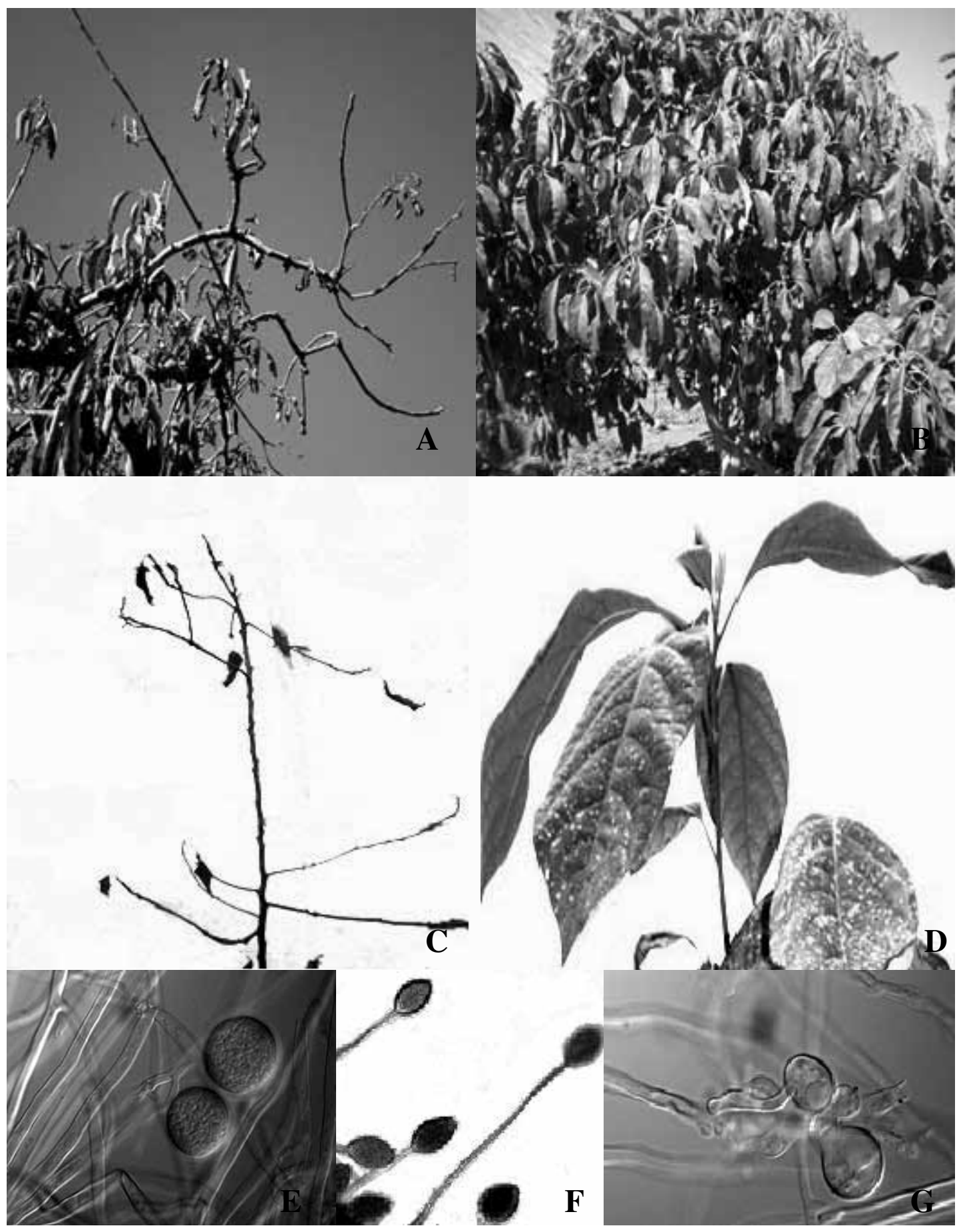

Figure 1. A: Infected avocado tree; B: Healthy avocado tree; C: Inoculated tree showing defoliation and death of branches; D: Control tree; E: Chlamidospores; F: Sporangia; G: Mycelium and hyphal swellings. Bars: E, F y G $=30 \mu \mathrm{m}$. 
Inoculated avocado trees developed typical symptoms of the disease: progressive death of foliage, reducing the size of new leaves and progressive chlorosis, first in the upper branches. Later there was defoliation and tree death (Figure $1 \mathrm{~A}$ and C). This is consistent with the reports of other authors (Zentmyer, 1980; Coffey 1991). Uninfected trees had abundant bright green foliage and well-developed leaves. Re-isolation from infected root verified the presence of $P$. cinnamomi.

The analysis of the $\mathrm{CO}_{2}$ date show significative reduction of $\mathrm{CO}_{2}$ assimilation $(\mathrm{p}<0.05)$ in inoculated plants (Table 3). This agrees with the results of Sterne et al. (1978) and Ploetz and Shaffer (1989). So the photosynthesis was significantly affected by the disease.

The morphometry of vegetative structures -mycelium, hyphae, hyphal expansion, chlamydospores, sporangia, antheridia and oogoniaof the isolates from Azapa and Codpa Valleys are characteristics of $P$. cinnamomi.

The bait method was effective for isolation of P. cinnamomi, and allowed recovery of the sporangia of the fungus.
Table 3. Net assimilation rate of $\mathrm{CO}_{2}$ in avocado trees inoculated with three isolates of $P$. cinnamomi.

\begin{tabular}{lc}
\hline Treatments (=Isolates) & $\begin{array}{c}\text { Net assimilation rate of } \\
\mathrm{CO}_{2}\left(\mu \mathrm{mol} \mathrm{m} \mathrm{s}^{-1}\right)\end{array}$ \\
\hline Control (sterile agar disc) & $12.65 \mathrm{a}$ \\
PCD1 (Codpa Valley) & $3.40 \mathrm{~b}$ \\
PAZ1 (Azapa Valley) & $5.99 \mathrm{~b}$ \\
PCD2 (Codpa Valley) & $6.08 \mathrm{~b}$ \\
\hline
\end{tabular}

Each value represents the average of four replicates. Different letters indicate significant differences using the Tukey test, $\alpha \leq 0.05$.

\section{Acknowledgements}

Thanks to project MAYOR-UTA 9710-12 and to the Regional Goverment of the Arica and Parinacota, through the project "Caracterización e identificación del agente causal de la baja productividad en el manejo del palto en el valle de Codpa: mitigación del problema a través de transferencia tecnológica" for financial support.

\section{Literature Cited}

Alvararado-Rosales, D.; Saavedra-Romero, L.; and ÁlvarezSánchez, A.

2008. First report of Phytophthora cinnamomi Rands associated with oak (Querqus spp) in Tecoanapa, Guerrero Mexico. Agrociencia 42: 565-572.

Besoain, X.; Arenas, C.; Salgado, E. and B. A. Latorre.

2005. Efecto del Período de Inundación en el Desarrollo de la Tristeza del Palto (Persea americana), Causada por Phytophthora cinnamomi. Cien. Inv. Agr. 32 (2). 97-103.

Chee, K.H. and F.J. Newhook.

1965. Variability in Phytophthora cinnamomi Rands. New Zealand Journal of Agricultural Research 8: 96-103.

Coffey, M.D.

1991. Cause and diagnosis; Avocado root rot. Calif. Grower 15 (17): 22-23.

Erwin, D.C. and O.K. Ribeiro.

1996. Phytophthora Diseases Worldwide. The American Phytopathological Society, St. Paul, Minnesota.USA. $562 \mathrm{p}$.

De Ferrari, L. and O. Ramírez.

1998. Manual de detección y control de plagas y enfermedades presentes y potenciales en plantaciones de pino y eucalipto. Concepción, Chile. Controladora de Plagas Forestales S.A.; BASF. Ed. Aníbal Pinto S.A. 114 p.

Dhingra, O.D. and J.B. Sinclair.

1985. Basic plant pathology methods. CRC Press, Boca Ratón, Florida, USA. 439 p.
Gardiazabal, J. and Rosenberg, G.

1998. Factores agronómicos a considerar en la implementación de un huerto de paltos, pp. 17-39. Seminario Internacional de Paltos, Viña del Mar, Chile, 4 al 6 de noviembre.

Instituto Nacional de Estadísticas (INE).

2007. VII Censo Nacional Agropecuario y Forestal. Santiago, Chile. [En línea] Disponible en: http://www. censoagropecuario.cl [Leído: 30 de agosto de 2009].

Latorre, B.

1992. Enfermedades de las plantas cultivadas. $4^{a}$ ed. Santiago, Ediciones Universidad Católica de Chile, 628 p.

Latorre, B., De Andraca, F. and X. Besoain. 1998. Tristeza del Palto. Aconex 59: 18-23.

Lauchi, A. and E. Epstein.

1984. Mechanisms of salt tolerance for plants. California Agriculture, Oakland, 38 (10): 18-20.

Messenger, B.J., J.A. Menge and E. Pond.

2000. Effects of gypsum soil amendments on avocado growth, soil drainage, and resistence to Phytophthora cinnamomi. Plant Dis. 84: 612-616.

Papadakis, J.

1966. Climates of the world and their agricultural potentialities. Ed. J. Papadakis. Buenos Aires, 174 p.

Ploetz, R. and B. Schaffer.

1989. Effects of flooding and Phytophthora root on net gas exchange and growth of avocado. Phytopathology 79 (2): 204-208. 
Sterne, R.E., M.R. Kaufmann and G.A. Zentmeyer. 1978. Effect of Phytophthora root rot on water relations of avocado: interpretation with a water transport model. Phytopathology 69: 595-602.

Vergara, C.

1957. Decaimiento o tristeza del palto. Simiente 27 (1-4): 53-55.

Swhiley, A.W., J.B. Saranah and L. 1. Forsberg.

1986. The control of Phytophthora root rot of avocado with fungicides and the effect of this disease on water relations, yield and ring neck. Australian Journal of Experimental Agriculture 26: 249-253.
Zentmyer, G.A.

1980. Phytophthora cinnamomi and the diseases it causes. The American Phytopathological Society (Ed.), Monograph $\mathrm{N}^{\circ} 10$, St. Paul Minnesota, USA. 96 p.

Zentmyer, G.A., J. Menge and H.D. Ohr. 1994. Phytophthora root rot. In: Ploetz, R.C.; Zentmyer, G.A.; Nishijima, W.T.; Rohrbach, K.G.; H.D. Ohr. (Ed). Compendium of Tropical Fruit Diseases. The American Phytopathological Society, St. Paul, Minnesota, USA. pp. 77-79. 
